\title{
30. Description and Discussion of Material bearing on Mimicry in South African Rhopalocera Col- Lected by Guy A. K. Marshall, and the Record of Observations made by him. (E. B. P.)
}

The splendid material which is described and discussed below has gradually accumulated as the result of $\mathrm{Mr}$. Marshall's kind and generous response to my desire for specimens for the Hope Department illustrating the fact that mimetic species and their models, and the members of large convergent or synaposematic groups, not only inhabit the same areas but fly together at the same time. The study of this material naturally led to conclusions and suggestions which it is hoped possess a general interest in relation to the doctrine of evolution and the important part which mimicry plays in it, as one of the chief evidences of the operation of natural selection. These more general discussions are placed under separate headings immediately after the groups whose study gave rise to them.

The last sub-section is placed under Mr. Marshall's name, being quoted in extenso from his letters.

\section{A. Black-and-White Amauris-like Group.}

The central model for the group described below is probably Amauris ochlea, but it was not captured on March 27, 1897, when five convergent individuals were taken at Malvern, near Durban, Natal. The group as captured is as follows:-

Planema aganice $\hat{\jmath}$.

Neptis agatha $\hat{\delta}$.

esebria + , var. with white markings.

2 Nyctemera leuconö̈.

The male Planema aganice is but an imperfect member of the group, the lighter markings being buff instead of white, as in the female. We thus find that the latter sex forms closer synaposematic resemblances than the male, when the two sexes differ. It is probable that this relationship between male and female will be found to be generally true of Muillerian mimics in which the sexes exhibit different degrees of likeness to the type of some group characterized by Common Warning Colours. Furthermore, the culmination is often reached in Muillerian 
mimicry, just as it is in Batesian where it has long been recognized, in species of which the female enters into a more or less well-marked membership of a group towards which the male has made no apparent approximation. Numerous examples will be found in the present memoir.

This interesting similarity between Muillerian and Batesian mimicry was probably unrecognized until 1894, when it was discovered by F. A. Dixey, ${ }^{*}$ because of the fact that in the first-known examples of Miillerian mimiery in tropical America, which are the most wonderful instances in the world, the convergent pairs and groups contributed by the Heliconinæ and Ithomiine and by different genera within each of these sub-families, are made up of species with males and females which are superficially alike.

Now, however, thiat the principle has been recognized by Dixey in many Neotropical Muillerian mimics with differing sexes and here in many Ethiopian, the explanation is doubtless the same as that suggested by Wallace (Trans. Linn. Soc. xxv, Pt. I, 1865) in the case of Batesian mimics, viz. the great importance for the species that the female, with her slower flight and the necessity to pause and lay her eggs, should gain to the full the advantages of that extra advertisement of warning coloration which is conferred by membership in a synaposematic group. This is the interpretation offered by Dixey in his 1894 memoir (q. v.).

Neptis agatha exhibits in an interesting manner that concentration of white markings into four large patches, one upon each wing (save that the fore-wing is invaded by a small portion of the hind-wing patch), and that disappearance of the other bars and markings, except for traces on the under-side, which are characteristic of many Ethiopian species of this genus, and doubtless indicate a synaposematic approach to the black-and-white species of Amauris and Planema of the Region.

It is too wide a subject to introduce into the present memoir, but I cannot forbear to allude to the evident synaposematic sensitiveness of the genus Neptis, leading it to form associations with local conspicuous Rhopalocera. Among the most beautiful of these are $N$. venilia and $N$. lactaria, which resemble the remarkable Danaine genus Hamadryas, especially upon the under-side. Again, the

* Trans. Ent. Soc. Lond., 1894, p. 298, note ; 1896, pp. 70, 71 ; 1897, pp, 319, 326-328, 330. 
likeness to Athyma and Limenitis must have struck every naturalist who has looked through the drawers of a tolerably large collection. Col. Swinhoe has recently called my attention to a Eupleca-like Neptis from China, N. imitans.

The resemblance of the genus Neptidopsis to Neptis seems, on the other hand, to have been due to mimetic approach on the part of the former towards the type set by the latter.

The Hypsid moth Nyctemera leuconoë seems to have independently adopted the same aposematic scheme of colouring as the genus Amauris, the only change in the direction of the latter dominant type being a slight broadening of the white bar crossing the fore-wings, a broadening which is at once recognizable when this and other African species of the moth are compared with their nearest Oriental allies. The conspicuous and almost certainly specially-protected Hypsidx strongly tend to enter into synaposematic association with other specially-defended forms in various parts of the world. Thus one species approximates towards Hamadryas, while, in tropical America, the smaller forms become transparent and resemble the smaller Ithomiinæ, while the larger (Pericopis) possess the warning coloration of species of Melinæa and Heliconius.

\section{B. Limnas chrysippus-like Groups.}

The first of these groups was captured on March 6, 1897, at Malvern, Natal. It consists of the eight following individuals :-

Limnas chrysippus ô.

" $\quad+\quad+$ var. alcippoides.

Hypolimnas misippus + , with pale hind-wings like the last-named insect.

H. misippus +, var. inaria.

Planema esebria \&, chrysippus-like type-form with white sub-apical bar to fore-wings and reddishbrown black-bordered hind-wings, the groundcolour extending on to the fore-wings. Acræa encedon $\hat{0}$.

A. serena, var. buxtoni, ㅇ.

A. doubledayi $\hat{\delta}$.

The latter individual, being a male, is not really a member of the group, inasmuch as it lacks the oblique 
sub-apical white bar present in the female of typical doubledayi. The presence of the male indicates, however, that the female flies with the other members of this chrysippus-like group, of which it forms an imperfect and outlying constituent. The male of serence also does not resemble chrysippus, while the female is an even more imperfect Miillerian mimic than the female of doubledayi. Nevertheless such cases are of the highest interest, inasmuch as they enable us to understand how mimicry arose in species which now exhibit a startling likeness. $A$. encedon, one of the most perfect Muillerian mimics of chrysippus, presents an equally close approximation in male and female.

The fact that the female of $P$. esebria should present two well-marked varieties, one of which falls into a blackand-white group convergent round the species Amauris, while the other, the type-form, enters the combination which surrounds L. chrysippus, recalls a principle already well known and probably correctly understood in the case of Batesian mimicry. When an abundant well-protected Acræa thus approximates to two very different Danaine patterns it is obvious that we are not necessarily driven to a Batesian interpretation of the forms of the female Papilio cenea, which approximate to the appearance of Amauris echeria as well as to the two other Danaine types alluded to above. The enemies of chrysippus and the species of Amauris are certainly not precisely the same, and it may well be an advantage to a Millerian mimic to secure that increased protection from insect-eating enemies which is conferred by belonging to two or more groups.

Furthermore, the Planema has come to resemble the Danaine and not the Danaines the Planema, and this probably indicates that the Danaine is on the whole the less attacked and the better known. It is probably of advantage to the whole group that the Danaine which set the pattern should still be the dominant member of the assemblage of which it is the centre. This dominance is favoured by the individuals of an abundant species joining two or more groups instead of throwing the whole of their number into a single one. In the case of Batesian mimicry, where the mimics are comparatively palatable and would be freely eaten if recognized, the advantage of this di- or trimorphism and the likeness to two or three models is even more obvious. 
A second group of the same type was captured in the same locality on March 30, 1897, and consists of six individuals :- -

L. chrysippes + .

H. misippus +, a pale patch in the centre of each hindwing.

P. esebria $\hat{\delta}$, buff sub-apical bar to fore-wing.

A. encedon $\hat{\delta}$.

A. serena, var. buxtoni $i$.

A. petrixa +.

The lack of correspondence between the varieties of the females of $H$. misippus and those of the central member of the group is well seen in these two sets. Thus one of the three females is the inaria form, although the llugii var. of chrysippus is almost unknown in S. Africa, while the other two suggest the appearance of the alcippoides var., which does indeed occur not uncommonly, but is not nearly so abundant as typical chrysippus. The female of $A$. petrica is another outlying member of the group, while the male is altogether outside it.

A third group, captured by Mr. Marshall at Salisbury on April 10, 1898, contains these species:-

\section{L. chrysippus + \\ $\left.\begin{array}{l}H . \text { misippus o } \\ 2 \text { A. encedon } \delta\end{array}\right\}$ all typical forms.}

A fourth group captured at the same locality on April 9, 1899, contains :-

2 L. chrysippus ô, o (Plate XIV, figs. 1, $1 \alpha$ ).

2 Mimacræa marshalli $\hat{\delta}$ (Plate XIV, figs. 2, 2a).

This beautiful Lycænid mimic presents in some respects a closer approximation to Acræa encedon (Plate XIV, figs. $3,3 a$ ) than to L. chrysippus, the primary model of both. Thus the character and contour of the sub-apical white bar of the fore-wing suggests that of the Acræa rather than the Danaine. In the two former the bar is more continuous, in the latter more obviously broken into discontinuous spots, attended by outlying smaller spots. Another far more important similarity between Lycænid and Acræa is brought about by the numerous conspicuous black spots which in both are scattered over the basal part of the under-side of the hind-wing. In other respects the 
under-side of the Lycænid presents a much closer approximation to the Danaine than does the Acræa. In wellmarked individuals there are fourteen of these spots in the Lycænid, nineteen in the Acræa. In place of these, the Danaine model possesses, in addition to the marginal white-marked spots and a single spot at the extreme base of the wing, only a row of three spots on the outer boundary of the cell in the female, with an additional white-centred black patch, marking the scent-pouch, in the male. The three spots along the outer margin of the cell are encircled with white, as are all the spots in the Lycænid; while the veins of the under-side of the hindwing in both are more or less emphasized with white. In these minor but distinct points the Lycænid approximates to the Danaine and not to the Acræa; and furthermore in the fact that the black spots of the under-side of the hindwing are hardly visible on the upper-side of the Lycænid, while all except the basal ones are as distinct upon the upper-as upon the under-side of the Acræa. In the Danaine they are very distinct although much smaller on the upperside, but as there are only three in the female and four in the male, the Acræa is in this respect much further from the other two than they are from each other, its distance being still further increased by a few (4-6) large conspicuous black spots on the ground-colour of the basal half of both surfaces of the upper wing. It is noteworthy that these points of divergence on the part of $A$. encedon are characters which it shares with a large number of related species. All the points mentioned above can be well seen in the six upper figures of Plate XIV, which should be compared with the six corresponding figures on Plate XV, showing the prevalent form of the Danaine model and its Acræine and Lycænid mimies much further north in British East Africa.

In the dark shade of the brown ground-colour the Acræa is much nearer to the Danaine as developed in S. Africa than the Lycænid, and upon the wing the black spots would probably make the Acræa appear still darker. The bright fulvous tint of $M$. marshalli is more of the shade of the Oriental specimens of chrysippus. This relationship appears to exist between many of the other African Miillerian and Batesian mimics of L. chrysippus and their model, and suggests that the Oriental bright shade is ancestral, although the Oriental intrusion is comparatively 
modern, as proved by the relatively small amount of mimicry, and that little very imperfect, in species peculiar to the Region. The fact that the bright Oriental shade still persists in many of the specimens of chrysippus from the north-east and probably other parts of Africa, supports the same conclusion.

Mr. Roland Trimen points out that the Mimacræa also resembles the female of the type-form of Planema esebria (Trans. Ent. Soc. Lond., 1898, p. 15).

Mr. Marshall gives the following account (1902) of the habits of this interesting insect:- "In its general habits Mimacræa marshalli, Trim., like Acræa encedon, is essentially a woodland (but not a forest) insect, and shows a marked fear of venturing out into open country. Limnas chrysippus, on the other hand, frequents both open and woodland stations. When quite undisturbed it flits about in a limited area of the bush with a slow flight exactly resembling that of $L$. chrysippus (see also pp. 481, 482), but when alarmed it is capable of flying with considerable speed, and dodges with great dexterity. When hard pressed it will occasionally rise right over the tops of the trees, descending into the bush again further on. But its usual method of escape is by dodging in and out among the treetrunks, then settling suddenly on the far side of one of them, which makes it extremely difficult to follow. It is in its resting habits that it differs most from the mimetic group to which it belongs, for I have never seen a specimen settle anywhere except on a tree-trunk, and then always with its head downwards, just like a Libythea or the brown species of Crenis. The Danainæ and Acræinæ, on the other hand, always rest with their wings hanging down, and usually in more exposed positions; indeed, I think it may be said that no species of these groups (in South Africa at least) ever settles upon tree-trunks. This habit is also a very unusual one among our Lycænidæ, one or two species of Teriomima being the only cases of its occurrence which I can recall. Despite the great resemblance of this Mimacria on its under-side to Acrixa encedon, yet its colouring when at rest is very far from conspicuous, and harmonizes a great deal better with its surroundings than might be supposed from an examination of the insect in the cabinet, especially as the fore-wings are so much depressed between the hind-wings as to quite conceal the sub-apical white patch. The species seems to be of 
considerable rarity; I know of only fourteen or fifteen specimens, all of which, except two or three, were captured by myself."

\section{The Origin and Meaning of the Three Chief Forms of Limnas chrysippus.}

I have often discussed the question set forth in the title of this sub-section with my friend Colonel J. W. Yerbury, who has observed this insect carefully in many of its localities, and is deeply interested in it.* He believes that the appearance of the various forms is controlled by environmental influences-dryness or moisture-acting upon the pupa at some critical period of special sensitiveness. The facts recorded below do not seem to be consistent with this interpretation.

My friends Mr. and Mrs. S. L. Hinde, who have kindly collected many specimens throwing light on problems to which I have given much thought (see also pp. 446, 447), sent me two series of forms of Limnas chrysippus, which are of special value in relation to this discussion.

The first set (of 15) was captured, almost on the sealevel, in the uniform damp heat of Mombasa, on May 6, 1900, and consists of four of the type-form of Limnas chrysippus ( $1 \quad \hat{\delta}$ and 3 \%), and eleven of the form klugii $(9$ $\delta$ and 2 f). All were taken in less than an hour on a spot of ground a few yards in extent. They thus afford a fair criterion of the proportionate numbers of the two forms.

The second set (of 13) was taken, at a height of about $5400 \mathrm{ft}$., at Machakos Road, on the Uganda Railway, on May 22, 1900, and consists of four of the type-form (3 $\hat{\delta}$ and 1 \&), one alcippoides ( $\hat{\delta})$, seven klugii ( $2 \hat{\delta}$ and 5 q), and one dorippus ( $\hat{\delta})$. These also were taken on a spot of ground a few yards in extent, in less than an hour.

Mr. Hinde has given me information as to the climate of the period in which the latter capture was made. It is printed on pp. 447,448 , but it is well to re-state here that May 22, 1900, was at "the end of a very dry wetseason in an exceptionally dry year." The specimens show the effect of these conditions, for they are on the average

* J. W. Yerbury, Journ. Bomb. Soc. Nat. Hist., 1892, p. 207. Col. Yerbury's observations on the species are also quoted by Dr. A. G. Butler in Proc. Zool. Soc. Lond., 1884, p. 478; 1885, p. 756. 
very much smaller than those bred from larvæ which fed on the more luxuriant food-plant in Mombasa. Examining the two series, we are driven to the conclusion that the Machakos larvæ were partially starved, probably by feeding on parched food-plant. Interesting and important inferences may be drawn from the comparison.

In the first place the specimens, so far from supporting the conclusion often arrived at from incomplete and, as I think, ill-regulated experiments, that males are produced by starvation, actually show a larger number of females in a smaller total of specimens than the set from Mombasa, viz. 6 out of 13 , as against 5 out of 15 . Even if the females had been very scarce at Machakos, nothing would have been proved in the direction of the determination of the sex of the individual by diet, for starvation pushed to the extreme of preventing the completion of development of many individuals is certain to kill off the heavier sex far more freely than the lighter. The results, however, show no abnormal excess of males, and in every way support a prediction firmly founded on the anatomical fact that the essential organs of sex, the testis and ovary, are already present, rudimentary, but perfectly distinct, in the larval stage.

A comparison of the two series furthermore indicates very strongly that the various forms of the species are not in any way due to environmental causes, but are inherent and hereditary. It is believed that klugii is due to drought, but there is a larger proportion of this form in the series bred in the moist heat of the coast than in that reared at high and dry Machakos. The great difference in conditions which is manifest in the different average size of the two series was powerless to effect any change in the inherent hereditary tendency of the individual to become either klugii or its modification dorippus, the type-form or its modification alcippoides.

This comparison of forms from adjacent localities under different climatic conditions leads to an inference which is precisely the same as that drawn from the comparison of forms from different localities under the same climatic conditions. The tropical forests of West Africa and the Malayan Islands are very similar as regards climate: in the first chrysippus occurs as the white-hind-winged alcippus, in the second as the type-form, a peculiar dark form inhabiting Java (L. bataviana). It is not necessary 
to pursue such comparisons further. So far as chrysippus is concerned, I know of no facts which support the hypothesis of the environmental production of the forms, and many which are inconsistent with it.

The only alternative hypothesis which presents itself is that of the operation of natural selection in determining the very different distribution of the various forms of chrysippus in the different parts of its range. And in attempting to solve this difficult problem I have been guided by the same principles which enabled me to suggest a meaning for the two widely-different seasonal phases of Precis, viz. the relation between insects and their enemies, the value of warning colours under certain conditions, their weakness and danger under other conditions. I believe that the condition of desert areas corresponds to that of the dry season, only differing in that they are more rigid, so that cryptic colouring is still more imperative. I therefore suggest that the klugii form is a development in a procryptic direction in areas where the struggle is so severe that even this most unpalatable and widelymimicked species must put off some of its aposematic appearance, viz. the conspicuous black-and-white apex of the fore-wing.

There is also a peculiar faintly greenish-orange shade in the area of the apex of the fore-wing under-side beyond the sub-apical white bar of chrysippus which is wanting from the corresponding part of klugii, the difference tending to bring about a further uniformity in the ground-colour of the under-side of the latter.

Furthermore, many specimens of klugii have a groundcolour quite different from that of even light individuals of the type-form, gaining a distinct sand colour. This is all the more striking in Africa, where the type-form commonly develops a dark rich fulvous ground-colour very different from the paler Oriental type.

This interpretation is based on the assumption that klugii has developed from chrysippus and not chrysippus from klugii, and no escape from this assumption seems possible. The main lines of argument are these. Island individuals, which are so generally ancestral, are chrysippus and only very rarely klugii, except near the metropolis of the latter form in Somaliland. Perfect and imperfect mimics, Batesian and Müllerian, are very large in number, especially in Africa. Probably not one of them mimics 
klugii and not chrysippus, a few mimic both, while the great majority mimic chrysippus alone. Again, l.lugii stands alone among Danaina, while the pattern of chrysippus is closely related to that of several other species and genera, such as Salatura. The distribution of 7lugii can be understood by supposing the desert region of Somaliland to be its centre. From this point it radiates, towards the east becoming gradually rarer, although it is well known in Karachi, and Colonel Yerbury even captured a single specimen in Ceylon, towards the south finally disappearing in South Africa, towards the Nile Valley, here also probably disappearing towards Central Africa. Chrysippus, or at least forms with a black-and-white apex to fore-wings, on the other hand, occur over the whole vast range of the species with the exception of certain parts of Somaliland.* The strongest argument is, however, one which is developed at the end of the section, because wide conclusions of great interest spring from it (see pp. 482-484).

The white-hind-winged alcippus was for a long time a great difficulty to me, but Mr. Marshall's suggestion (see p. 479) that it is a further development in the direction of still more efficient warning colours than the type-form seems to me to be sound, especially considering its distribution in the abundant life of the tropical West Coast, and considering the fact, of which Mr. Marshall assures me, that it is much more conspicuous on the wing.

I have for a long time thought that this great development of white, combined with the darkening of the fulvous ground-colour so common in African specimens and marked in alcippus, may indicate an incipient synaposematic approach to the black-and-white Danaina of the genus Amauris, and the large black-and-white Acræinæ of the genus Planema.

It is in favour of this view that the darkened groundcolour appears to be a recent development, although it has arisen in the Ethiopian region-the ancestral home of the species, if we may judge by the much larger number of mimics which resemble it in this part of its range. I believe the lighter ground-colour of chrysippus in India and, with certain exceptions, the East generally, formerly

* Consult Dr. A. G. Butler's map of the distribution of the forms of chrysippus, on Plate XLVI, aceompanying his paper in Proc. Zool. Soc. Lond., 1884, p. 478; also by the same author, Proc. Zool. Soc. Lond., 1885, p. 756. 
prevailed in Africa, because so many of its African mimics retain this shade rather than that now borne by their model, and because chrysippus itself often exhibits the paler tint, especially to the north and east* of the African continent (see pp. 471, 472.).

I quote below extracts from several of Mr. Marshall's letters dealing with the hypothesis which I have here set forth, and also referring in other ways to this interesting butterfly and its forms.

"Malvern, May 14, 1897.-I was interested to hear that the $L$. chrysippus, var, alcippoides, I sent resembles the West Coast specimens. Personally I have never come across that variety commonly, and those I have taken have mostly been very slightly marked with white, but Mr. G. H. Burn, who has collected for some years in the Tugela Valley, near Weenen, says they are not uncommon there, but apparently are most prevalent in the early winter (it is a very hot dry district), and they are frequently marked quite as strongly as the one I sent you."

"Salisbury, Jan. 24, 1900.-Referring to your very interesting remarks on $L$. chrysippus, I was much struck by your theory with regard to klugii. The only point, however, on which I do not feel satisfied is whether we can consider the colouring of this variety to be really protective. Of course I have never seen it in life, but I have seen many of the inaria form of Hypolimnas, and I must confess that the insect is very far from being inconspicuous; and even apart from colour it must be remembered that slowness of flight is a very important factor in rendering an insect conspicuous (compare our large and powerfully-armed but soberlycoloured wasps of the genus Belenogaster). Again, it would seem hardly consistent to regard the colouring of klugii as protective if we rank that of the smaller Acræas, which inhabit some at least of the same areas, as among the warning colours. It would therefore strengthen the theory if some other use could be assigned to the klugii coloration, though none occurs to me at the moment. Of course the correlation argument might be brought forward; but while thoroughly appreciating Meldola's masterly defence of this principle, I must admit that I have a distinct distrust in its use in such cases, as it means virtually begging the question. I cannot altogether gather from your remarks what are your reasons * See F. A. Dixey in Proc. Zool. Soc., 1898, p. 373, note. 
for supposing that the lighter Asiatic form is the older [see pp. 471, 476]. On general principles it would seem that swamping would be likely to keep the species more or less constant in its ancestral home, whereas those specimens that wandered further afield would probably tend to vary along slightly different lines; but perhaps I have not properly caught your idea. The case of alcippus would be a great deal more difficult to explain satisfactorily, seeing that it occurs also at Aden ; and Butler says that examples sent from such places as Monbuttu, Wadelai, etc., by Emin Pasha, showed every gradation from chrysippus through alcippoides to alcippus; further, if I remember rightly, you wrote me that an example I sent you from the Tugela had the white developed as strongly as in any West Coast specimen, and Burn said they were by no means uncommon there."

[“A. G. Butler records (Proc. Zool. Soc., 1896, p. 243) Captain Nurse's statement that in Somaliland he bred all four forms of chrysippus from quite similar larvæ." G. A. K. M., 1902.]

"Salisbury, June 26, 1900.-Referring to the question of Limnas klugii, although I fully appreciate the value of your arguments, yet I must confess that when looking at the matter from the point of view of an opponent of mimicry, it seems at least open to criticism. The difficulty seems to lie in the fact that the same coloration would thus have to be regarded as both protective and warning. Now you have said that in desert regions insects would be more liable to attack owing to the paucity of insect life, and I should be glad to know whether you have any special reasons for adopting this view, as I have no experience of what the conditions of life really are in such localities. But don't you think that it is more likely that the struggle for existence would be principally against climatic conditions and not so much a competition with other organisms, and that thus probably insects would have a better proportionate chance of finding a living than would the vertebrates as compared with more fertile regions? If this were so it would follow that insects would be comparatively freer from attack in desert regions, and this would afford us another explanation of the Klugii phenomenon. We might presume that the less conspicuous klugii colouring was the more ancestral (as seems not unlikely), but that in the more fertile regions where 
insectivorous vertebrates and invertebrates are so much more plentiful, this coloration was not sufficiently striking to guard it from the tasting experiments of these enemies, and thus the white bar would be gradually developed. The typical form would therefore supplant llugii in all places where there was greater need of more efficient warning colouring, and the latter form would only survive in those tracts where only a limited number of insectivorous enemies could exist. Such an explanation would further throw some light on the additional development of white in the hind-wing of alcippus in the prolific West Coast belt, where the increased number of vertebrate enemies requiring to learn by experience renders an additional conspicuousness advantageous. It seems to me that if such an explanation could be maintained it would be more consistent with our general views; but of course the matter hinges on the conditions of life in desert tracts, which is merely an assumption on my part."

"Salisbury, Sept. 21, 1900.-I was much interested in your remarks on the subject of klugii, and I quite agree that now that you have shown that my premise as to the conditions of life in desert countries is erroneous my contention falls to the ground. I should like to know how the range of the inaria form of misippus falls in with your proposition, and also whether you find the variety of Acria encedon without the white bar to follow the same range as klugii. I have found this variety [daira] extremely rare in S. Africa, but a correspondent wrote me from Beira the other day that it was not uncommon there and promised to send me specimens."

"Estcourt, Natal ; Oct. 15, 1896.-I had thought Acræa encedon might be mimetic, but it must be a case of convergence-the type towards Limnas chrysippus and the variety lycia towards esebria. That this latter is the case I am led to believe by the fact that in Mashonaland only the type-form occurs and there esebria is also absent, whereas along the South-east Coast where the latter is plentiful, lycia occurs, and when I met with it in Durban I was struck with its resemblance on the wing to the whiter specimens of esebria, though this is not so apparent in the cabinet."

"Malvers, Natal; Feb. 21, 1897.-The case of $H$. misippus is however more puzzling than the Euralias which mimic Amauris. The inaria form of the female is 
often cited as a mimic of L. chrysippus, var. klugii. Now this is by far the commoner form of the female misippus in S. Africa, whereas klugii appears to be extremely rare, in fact the single specimen recorded by Trimen is the only one I know of. How then can it be said to be mimicked by inaria? Again, misippus is recorded in several places in South America, where I believe chrysippus does not occur. It seems to require further investigation."

"Umkomaas Mouth, Natal; Sept. 3, 1897.-I certainly think that I have more frequently seen Hypolimnas misippus (female) in company with $L$. chrysippus than with its own male. The latter is fond of haunting the tops of kopjes in company with various species of Precis (which always occur in such localities), but I have never seen the female do so, neither does chrysippus."

The range of the forms of encedon corresponds remarkably well with the forms of chrysippus. Mr. Marshall states above that the Klugii-like form daira is extremely rare in the south where klugii is absent. Passing northward on the east side of the continent it gradually increases in proportionate numbers till it preponderates over encedon where klugii preponderates over chrysippus. On the West Coast all forms seem to occur, but recently the white-hind-winged alcippina (Plate XV, fig. 7) has been found there in greater numbers than elsewhere. (Aurivillius, Rhopalocera Ethiopica, Stockholm, 1898, pp. 533, 534; Poulton, Proc. Linn. Soc. Lond., 113th Session, p. 6 , Report of Meeting Dec. 20, 1900, where however the name encedon is erroneously printed unicolor:) The distribution of the Lycænid mimic corresponds equally well, marshalli with chrysippus in the south (Mashonaland), dohertyi with the predominant klugii in British East Africa. H. misippus o shows upon the whole an almost complete lack of correspondence, for inaria is common nearly everywhere, while klugii is confined to the range described on p.476. In British East Africa, however, misippus o corresponds well with the two forms of its model; while on the west, where alcippus is the only form, the want of geographical coincidence is most striking, for the inaria form is relatively abundant, while neither in it nor in the type-form, so far as I am aware, is there any special tendency towards the development of white in the hind-wings. It is a striking fact that the Acræine mimic should exhibit so close a coincidence with the geographical range of its Danaine 
model, while the Nymphaline mimic shows such a marked want of .correspondence. The comparison may help naturalists to realize the great importance of Miillerian mimicry and the searching selective process which has brought it about.

I have for many years attributed this want of correspondence between the commonest mimic of chrysippus and its model, to the wide-ranging powers of the former butterfly and its great tendency to wander, combined with some special protection which there is reason to believe it possesses, rendering its resemblance synaposematic rather than pseudaposematic. There are in the Hope Department three females (two of them inaria) and two males of $H$. misippus captured out of a swarm through which the ship Winefred passed in May 1893, when she was on the Atlantic over 500 miles from land (Ent. Record., vol. xii, No. 11, p. 315). The Müllerian resemblance of misippus o to chrysippus was suggested by the present writer at the meeting of the American Association for the Advancement of Science in 1897 (see vol. xlvi, p. 242, where arguments in support of this conclusion may be found). Extracts on this subject from Mr. Marshall's letters are printed below :-

"Malvern, Natal; Oct. 7, 1897.-I fear I cannot at present accept your suggestion that Hypolimnas misippus is itself protected. I may be wrong, but in these matters I depend more than anything on the habits and actions of the insects as I have seen them when undisturbed and when frightened. There is to my mind a radical difference between mimics and their models (as opposed to convergent forms) which is often very difficult to define. There is also a structural difference which appeals to me, so that I believe I could almost tell one from the other with my eyes shut merely by the feel of it in the net. To give an instance: when on a short holiday trip to the rich Mazoe Valley in December 1894, I staried out on Christmas Day with the set purpose of catching something "good" to commemorate the occasion. While strolling along the narrow belt of thick bush which there fringes the river, I saw flying leisurely in front of me what I took to be a very small and brightly-coloured specimen of Limnas chrysippus. I coveted it, and a few seconds later it was in my net, through the folds of which I could but indistinctly see it, so that I was still deceived. But no sooner

TRANS. ENT. SOC. LOND, 1902.-PART III. (NOV.) 32 
had my finger and thumb met across its thorax than my heart beat high with that keen excitement that every ardent entomologist feels when he has found some unexpected treasure-for I knew I had got a new mimic of chrysippus! A short inspection showed it to be a new Lycænid-a Mimacræa (since named M. marshalli, Trimen). On the other hand, when I caught my first specimen of Aletis here in Malvern in March 1893, I remember it puzzled me much, for I felt sure it was not a mimic of chrysippus, and yet I could not understand the reason of the colouring, for I was then unaware of Muiller's theory.

"To return to misippus, although I admit it is a somewhat difficult case, yet the fact that it has elected to mimic what I take to be the hardiest and best-protected butterfly in Africa, combined with the general adaptability to varying conditions which one would expect it to share with its nearest allies the Junonias, must I fancy go a long way towards explaining its wide range and comparatively large numbers. There is another factor that must not be overlooked, and that is that through a considerable portion of its range in South-east Africa at all events it is the only butterfly which shows mimicry of chrysippus. This is particularly noticeable on the rolling grass veldt of the inland plateaux where chrysippus is particularly abundant.

"I think your idea as to the latter insect having originated in Africa is excellent and in every way most probable."

"Salisbury, March 6-10, 1898.-The facts that you mention with regard to Hypolimnas are certainly very curious, and would seem to be only explicable by presuming the species you mention to be protected. But in the case of Hypolimnas misippus, after reviewing the general habits and attitude of the female, I cannot bring myself to believe that it is anything but a true Batesian mimic. Might it not be a similar case to that of the genus Papilio, in which we have the distinctly protected and distasteful $P$. coon and at the same time the clearly mimetic P. cenea?"

\section{A Study of Mimetic Forms may enable us to reconstruct} the Lost Stages through which the Older Model has passed.

If klugii has been derived from chrysippus we should expect to find traces of the markings of the latter upon the wings of the former. And as a matter of fact faint 
indications of the white sub-apical bar of chrysippus can be detected in klugii, especially at the points on the costa and the hind margin which the two ends of the bar would have reached. Very faint traces of the course of the bar between these two points can be made out in certain individuals (Plate XV, fig. 1), while occasionally they are very distinct, especially upon the under-side (Plate XV, fig. $1 \alpha$ ). Looking at these two figures, and comparing them with Figs. 1 and $1 a$ on Plate XIV, it is impossible to resist the conclusion that we see before us the vestiges of a fading character and not the rudiments of a developing one. It is interesting to note that one of the slightly intermediate varieties of klugii here represented (viz. Fig. 1, Plate XV) was an individual captured by Mr. and Mrs. Hinde at Machakos Road, and that three or four others of the same set showed similar tendencies. It may be that the unfavourable conditions (see pp. 473, 474), although unable to change one form into another, nevertheless administered a shock which caused a slight reversion towards the ancestral type in some individuals.

The three great mimics of both forms of chrysippus, the female of the Nymphaline, Hypolimnas misippus with its inaria form mimicking klugii; the Acræine, A. encedon* with its klugii-like form daira; the Lycænid Mimacræa marshalli with what I believe to be merely its klugii-like form dohertyi, all these show precisely the same thing as their model only in an exaggerated form, because the mimic follows its model and therefore still exhibits stages which the latter has left behind. Comparing the upperand under-side of the chrysippus-like Lycænid on Plate XIV (Figs. 2 and $2 a$ ) with those of the klugii-like form on Plate XV (Figs. 2 and $2 a$ ), there can be no doubt that the latter developed from the former. The white bar of marshalli (Plate XIV) can still be distinctly traced in dohertyi (Plate XV), not indeed as a white bar but as a very faint paling of the ground-colour over a sub-apical area, the outline of which exactly

* The first recognition of the mimicry of chrysippus by encedon, and indeed of the existence of Muillerian mimicry in the Ethiopian Region, was first brought forward at the meeting of the British Association at Toronto in 1897 (Report, p. 689). Aurivillius (Rhop. Eth. 1898, p. 533) states that the resemblance had not been previously noticed. The account given by Aurivillius is however far more complete than that in the brief abstract here referred to, and is also accompanied by illustrations. 
corresponds to the bar itself. The comparison to a pseudomorph suggests itself; the bar is indeed absent but its shape is there. The case of the Acræine mimic is still clearer, Figs. 3 and $3 a$ on Plate XIV bearing the same relationship as that above described in marshalli-dohertyi, to Figs. 3 and $3 a$ on Plate XV. The same "pseudomorph" of the white bar can be seen in the latter, while in Figs. 4, 5, and 6, on Plate XV, some by no means uncommon intermediate varieties between encedon and daira are represented. Fig. 7 shows the form alcippina which resembles alcippus, the white-hind-winged chrysippus.

When a geologist finds a recognizable fragment of one rock included in a stratum of another, he is usually safe in inferring that the latter is the younger. With equal confidence the zoologist may conclude that the mimicking species is younger than the species it mimics. The latter must have been in existence before the former attained a resemblance to it. From this point of view the comparison between chrysippus-klugii and their mimics is of intense interest. Chrysippus and klugii are now well defined the one from the other, and it is probably impossible or at least extremely difficult to get a series of intermediate forms between them. If we had not the mimics we might well believe that klugii arose ready-made from chrysippus by a process of discontinuous or transilient evolution. But two of the younger mimics are very common and widespread, and both misippas-inaria and encedon-daira present us with abundant varieties showing every grade of transition from the one form to the other. Of the Lycænid less can be said. It is still extremely rare (see pp. 472,473 ) and at present only known in two widelyseparated areas. But even in it the gap marshalli-dohertyi has been shown above to be much less wide than that of chrysippus-klugii. We are led to believe from this comparison that in some earlier age the two forms of the Danaine model existed in the stage now reached by their commonest mimics, and, like these, were connected by a series of abundant intermediate varieties which have since been obliterated by selection.

\section{E. Amauris echeria-like Group: Marked Secondary Resem-} blances between the Forms mimicking echeria.

This species of Amauris, with its very characteristic rectangular buff patch on the hind-wing and buff or white- 
spotted fore-wing, is the dominant Danaine of South Africa, and extends in considerable abundance right up the east and east central parts of the continent well into British East Africa. It is a centre of convergence for several Nymphalinæ and Papilioninæ in the same district.

An interesting group, captured by Mr. Marshall at Malvern, on March 25, 1897, consists of the following species :-

Amauris echeria, var. albimaculata $\hat{\delta}$.

2 Euralia mima .

Papilio cenea +, cenea-form, with white spots on forewing, like the var. albimaculata of A. echeria.

Papilio leonidas, var. brasidas.

The last-named Papilio is a somewhat outlying member of the group, being separated from the others by the patch on the hind-wing, which is white with a faint greenish tinge, instead of buff. The general arrangement of the light markings on the black ground is however similar, and Mr. Trimen states that "it was in the habit of settling precisely in the way affected by the Amauris, viz. on a projecting leaf or twig, with the wings closed and hanging downward, and in this exposed position remaining motionless for a considerable time" "South African Butterflies," vol. iii, 1889, p. 216). In two points, viz. size, and contour of the wings, it is more like the Danaine model than any of the other above-mentioned species.

The most interesting point about the group as a whole is, however, the undoubted secondary resemblance between the species which primarily resemble the Amauris. The secondary resemblance is, moreover, even stronger between $P$. cenea and the Euralia than between either of these and $P$. brasidas, that is to say, the species exhibiting a closer primary mimicry also exhibit a closer secondary mimicry. This fact suggests that the secondary resemblance is of permanent value and not a mere phase which will ultimately be lost in the primary resemblance. Mr. Marshall informs me that these secondary mimetic resemblances are still more marked upon the wing, so that a naturalist may often be sure that he sees before him a mimic of echeria or of a black-and-white Amauris, but cannot in any way distinguish the mimic itself as Papilio, Pseudacrea, Hypolimnas, etc. 
The points in which the mimics of $A$. echeria converge together and diverge from their primary model are as follows:-

(1) Size: They are much larger than their primary model. Brasidas is in this respect intermediate.

(2) Scalloped outline of hind-wing; feebly marked in brasidas. Slight indications of scalloping are intensified in echeria by the fringe being marked by two white spots in each of the shallow concavities. This is only distinct in some individuals, apparently chiefly from the northern part of the range. The marked concavities of the mimics are also intensified by whiteness.

(3) Elongated oval shape of largest spot in fore-wing, viz. the spot below the cell, while that of the model is nearly circular. The long axis of the oval spot furthermore assumes the same direction in each of the three species, while that of echeria is entirely different.

(4) The much greater prominence in all three mimics of the sub-marginal row of white spots on the upper-side of both wings.

(5) Strongly-marked black internervular rays pass inwards from the margin of the hind-wing of Euralia and invade the periphery of the ochreous patch, uniting with the black veins to make up a pattern of radiating dark lines. The radiate appearance of the under-side is even more prominent than that of the upper-side. Papilio cenea of is very similar, except that the upper surface exhibits only faint indications of the character (which however is strongly marked in the hippocoon form resembling Amauris dominicanus).*

Some of these differences between mimics as a whole

* In this respect, viz. the prominent development of internervular rays on both surfaces of the hind-wing, the hippocoon form of the Western $P$. merope presents a far closer resemblance to its co-mimic Euralia anthedon than to the primary model Amauris niavius, and similarly the hippocoon form of the Southern and Eastern cenea to Euralia wahlbergi than to Amanris dominicanus. Not only is there the conspicuous radiate appearance wanting in the Danaine model, but the white centre of the upper surface of the wings deepens gradually at its margin into black in both Papilio and Nymphalid, while the margin of the corresponding white area in the Danaine exhibits an extremely sharp and abrupt transition into black. 
and their primary model are less pronounced in the northern part of the range, in British East Africa, where the Amauris is often larger and commonly possesses far more distinct sub-marginal spots on the upper-side. It is interesting to compare other mimics of echeria with the members of the group captured by Mr. Marshall at Malvern on March 25, 1897.

The female of Pseudacræa tarquinia is a poorer mimic of echeria than Euralia mima and Papilio cenea + , although upon the wing the resemblance is doubtless strong. In size it closely approaches the model : it has a slightly-scalloped border, and an irregular oval spot with a direction similar to that of the other mimics; the marginal spots are small as in the southern echeria. On the under-side of the hind-wing is a basal brown patch with conspicuous round black spots as in many Planemas. In the development of internervular black stripes invading the squarish ochreous patch on the hind-wing it resembles Euralia and diverges from the Danaine model.

The female of Papilio jacksoni, in the shape and direction of the spot below the cell on the upper-side of the forewing, far more closely resembles echeria than any other mimic I have seen. On the other hand, the hind-wing is deeply scalloped, the effect being much intensified by white-margined concavities, the sub-marginal spots are as a whole larger than those of any other mimic, while the under-surface of the hind-wing exhibits very little approach towards the Amauris, retaining the basal, blackspotted brown triangle of the male, that well-known synaposeme and pseudaposeme of many Ethiopian Papilios, Planemas, Acræas, Elymnias, Pseudacræas, etc., unknown in the Ethiopian Danainx. Thus, in addition to its primary mimicry of echeria, var. albimaculata, jacksoni manifests secondary mimetic resemblance to the former group of Rhopalocera, especially the Planemas, and also an approach to other mimics of echeria in its conspicuous sub-marginal spots and deeply-scalloped border. The general effect of the spotting of the fore-wing is also more like that of $P$. cenea, and even of Euralia mima, than its primary model.

The female of the south-eastern Papilio echerioides is very similar to that of jacksoni, but the spot below the cell of the fore-wing is oval and in shape and direction more nearly resembles that of Papilio cenea. 
F. The Origin of the black-marked, golden-brown Triangle at the base of the Hind-Wing under-side in many Ethiopian Butterfies.

Mr. Roland Trimen, F.R.S., considers that the blackmarked, triangular, golden-brown basal patch on the underside of the hind-wing of the female $P$. cynorta which mimics Planema gea, and P. echerioides [and we may now add $P$. jacksoni] "points to the inference that mimicry of the Planema group was in both these Papiliones the earlier tendency, and has only more recently been diverted in the direction of Amarris in the case of the Southern species"; for "this character is in the of of cynorta and echerioides even more developed than in the $\mathrm{q} s$, and is in direct mimicry of the Planema" ("South African Butterflies," vol. iii, 1889, p. 258). But if in the female of cynorta, which is admitted to be an excellent Planema mimic, this very character is reduced, how can it be believed that its greater development in the male is a case of direct Planema mimicry, seeing that in every other respect this sex, if a mimic at all, is a most imperfect one?

A comparison of the Papilios and Planemas with the most remarkable development of this warning character at the base of the under-side of the hind-wing renders it probable that in this respect the latter have acted as Miillerian mimics rather than models. The character is far more highly developed and specialized in a section of Ethiopian Papilios than in any of the Planemas: it also appears in forms which are unknown, and accompanied by other warning characters which are also unknown in the Planemas; it reaches its highest development in species which do not mimic Planemas. It is also probable that the conspicuous, sharply-outlined white band of the male echerioides, cynorta, etc., nearly alike on both upper- and under-sides, is a warning character peculiar to this group of tailless Ethiopian Papilios. In the most stronglymarked species, with sexes nearly alike (zenobia, cypræofila, etc.), the outer margin of the band on the fore-wing is coarsely serrated in a very characteristic manner on both surfaces. Furthermore (in cypræofila, gallienus, etc.), another warning character of great interest is added in the row of large conspicuous marginal white spots on both surfaces of the hind-wing and smaller ones on the fore-wing. In this respect this group of Papilios presents an exact 
negative of the positive form of synaposeme characteristic of the Pierine genus Mylothris. Thus very striking warning characters are peculiar to this section of Papilios, the fifth or Zenobia Group of Aurivillius; and, furthermore, the character we are specially considering, the blackmarked basal patch of the under-side of the hind-wing, assumes a form which is unknown in Planema, being traversed by blackened veins and broader black internervular lines. In the species of Papilio last mentioned there are no spots upon the brown triangle, only these strongly-marked radiating lines. In zenobia and still more in the male cynorta a few spots are added by modification of some of the other markings, and it is probable that this slight change is a late diaposematic response to Planema, made after the latter had gained the golden-brown triangle in Miillerian mimicry of these dominant Papilios.

Another important point is the fact that the goldenbrown triangle is larger in the females than the males of cypraofile and zenobia which do not mimic Planemas, smaller, as has already been pointed out, in the females of the species which strongly exhibit this Miillerian approach to either Planema or Amauris.

It must also be remembered that Papilios may be excessively unpalatable to insect-eating animals as a whole. Thus Mr. Frank Finn concludes that $P$. aristolochix is more distasteful to birds than Danainæ, Acræa violx, and Delias eucharis (Journ. Asiat. Soc. Beng., lxvii, pt. ii, 1897, p. 614).

The facts and arguments set forth above render it probable (1) that the golden-brown triangular patch first arose in the Zenobia Group of Ethiopian Papilios; (2) that it was later reproduced on a smaller scale by the Acræine genus Planema, the Acræine round black spots contrasting with the ground-colour in place of the radiating black lines of the Papilio; (3) that, later still, other widely-separated genera reproduced the character in the form it had assumed in Planema, e. g. Pseudacrex, Elymnias, etc., while a reciprocal (diaposematic) tendency (see p. 426) to approach the Planema form is seen in certain species of the Zenobia Group of Papilios. Several species of the group have females mimicking Acræines or Danaines. In the three of these which were examined the males exhibited the above-described diaposematic tendency, while the females possessed a greatly-reduced but otherwise similar triangular patch. 
Hence this characteristic widespread Ethiopian synaposeme and pseudaposeme has probably originated in a diaposematic fusion of the triangular golden-brown patch of the Zenobia Group of Papilios with the scattered circular black spots which are characteristic of Ethiopian Acræas. I have made much use of Aurivillius' admirable "Rhopalocera Ethiopica" in this section which is devoted to the discussion of an under-side synaposeme, although the distinguished author himself maintains that mimetic resemblance is almost confined to the upper-side of butterflies' wings - a very strange conclusion (loc. cit., p. 535).

\section{G. Compound Group containing Representatives of all the three previously described. Species probably entering two Groups.}

The groups described above fly together, and thus represent in a compound group the chief types of butterfly coloration which a young insect-eating animal of South and Eastern Africa requires to learn, by a trial of one or more representatives. The following members of the three groups were captured by Mr. D. Chaplin at Berea, a suburb of Durban, on April 5, 1896, and are now in the Hope Department.

Black-and-White Group. Echeria-Like Group.

Amauris ochlea.

Planema aganice + . Amauris echeria, var. albimaculata. Euratia mima.

\section{Chrysippus-Like Group.}

Limnas chrysippus $\hat{\delta}$.

2 Hypolimnas misippus $\hat{\delta}$, o type-form.

2 Acrea petrixa of o.

2 Acraca encedon, type-form and var. Lycia.

That the same species may produce two or more forms entering as many groups is well known, but, as a rule, such polymorphism is confined to the female sex. In the polymorphism of Acrack encedon, however (see pp. 483, 484), we have a case in which both sexes are present in the various forms, and although the relative numbers of the forms are very different and certain of them may perhaps be absent from a district, I know of no case in 
which one alone is found in any part of the total range of the species. Hence the polymorphism, although partially a distributional phenomenon, is not entirely so. On the other hand, I know of no example among the Lepidoptera in which a species is at the same season divided into two sub-equal sections throughout its range, each containing both males and females, and each section mimicking a very different model. Among Diptera, the European Volucella bombylans and its form mystacea supply good examples; and now Mr. Marshall has collected evidence which makes it in the highest degree probable that the Lepidoptera are not without such cases. He brings convincing support for the belief that Euralia wahlbergi and $E$. mima are the two forms of a single species. It is greatly to be hoped that Mr. Marshall may be as successful in establishing this interesting and unique case, as he has been in the marvellous seasonal transformation of Precis. His evidence is set forth in the following quotations from his letters :-

"Umkomaas Mouth, Natal; Sept. 3, 1897.--In my own mind I am pretty well convinced that Euratia mima and wahlbergi are one and the same species which has developed two mimetic forms as in Papilio cenea, but that in this case both sexes are concerned. My reasons for so thinking are that they have been taken in coitu several times, that specimens occur presenting intermediate coloration, and also that the two forms are always found together whenever they are met with in any number. I have not often been fortunate enough to see these congregations, but I remember seeing some thirty or forty specimens, comprising about equal numbers of each form, collected together on the side of a steep shady kraantz along the Palmiet River. Mr. A. D. Miller, who has collected for many years in Durban, tells me this is by no means uncommon, and that they congregate particularly in the afternoon when going to roost. Mr. C. N. Barker tells me that some years ago he came across a large number of both forms on a large tree on which they had evidently bred, for many of them had only just emerged, and some had not their wings fully developed. This shows that they are also associated in their earlier stages."

About the time when this passage was written Mr. Marshall presented to the Hope Department a set of eight individuals of these Euralias, viz. four of E. mima (2 $\hat{\delta}$, 
2 f), and four of E. wahlbergi $(3 \hat{\delta}, 1$ \&), which he had captured on the Umbilo River, near Durban, Natal, on June 28,1897 . His account of the habits of this little company is given below.

"Malvern, Natal; Oct. 7, 1897.-The specimens of Euralia mima and wahlbergi were captured going to roost together on a small clump of ferns under a steep kraantz between 3 and 4 p.m. Although disturbed a good many times in my efforts to catch them, they always returned after some minutes. There were two others which were too tattered to keep, and two more that I failed to catch."

If Mr. Marshall's conclusion be established, it follows that the corresponding and closely-allied mimetic West African forms Euralia anthedon and E. dubia, connected like wahlbergi and mima by intermediate varieties, are similarly the dimorphic forms of a single species.

H. Groups of Synaposematic Acroas captured at the same Place and Time.

Professor Meldola first suggested the use of Fritz Miiller's principle to explain "the prevalence of one type of marking and colouring throughout immense numbers of species in protected groups, such as the tawny species of Danais, the barred Heliconias, the blue-black Euplocas, and the fulvous Acræas" (Ann. and Mag. Nat. Hist., ser. 5, vol. x, 1882, p. 425). As an example of Muillerian mimicry in the last-named group, I was anxious to obtain convergent species captured in one place and at one time. Mr. Marshall very kindly obtained two such groups for me. The first was captured by him on Dec. 31, 1898, at Salisbury, and contains the following species:-

6 Acrea doubledayi, var. axina, 4 ईิ 2 + (ô Fig. 1, 우 Fig. 2, Plate XVI).

4 Acrixa caldarena, 3 ๙ 1 o ( 1 Fig. 3, o Fig. 4, Plate $\mathrm{XVI})$.

4 Acræa nohara, var. halali, 2 f 2 우 (s Fig. 5), 우 Fig. 6, Plate XVI).

2 Acræa violarum, var. asema, 2 \& (Fig. 9, Plate XVI).

2 Acraca rahira, $1 \hat{\delta} 1$ \& (ô Fig. 7 , q Fig. 8, Plate XVI).

All these species are of approximately the same size and shape of wing, colour, and pattern, rahira being furthest 
removed from the average appearance of the group, while caldarena is an outlying mernber in one respect only, viz. the pronounced apical black patch on the fore-wing. The brightly-coloured males and the brightest of the females of all these species would closely resemble each other on the wing, including the male of violarum, which was not captured on that particular day; and similarly a uniform effect would be produced by the darker females. The under-sides of all species except rahira are superficially alike. The strong superficial resemblance is well shown in Figs. 1 to 9 on Plate XVI.

A second group was captured at Salisbury on Jan. 7, 1899, and contains the two following species:-

$$
\begin{aligned}
& 2 \text { Acræa anemosa } \hat{8}+\text { ( }(+ \text { in Plate XVI, fig. 10). } \\
& 2 \text { " natalica }+ \text { (Plate XVI, fig. 11). }
\end{aligned}
$$

These large Acræas are obviously very different in the details of coloration, but the positions in which the black marking of the upper surface are massed on the fulvous ground-colour are almost exactly the same, the only marked difference being the presence of numerous black spots in the first-named species which are almost absent in the second. Mr. Trimen speaks of anemosa as "in habit and general colouring very near natalica" (loc. cit., vol. i, p. 156). The under-sides are far less alike, but there can be no doubt about synaposematic convergence having occurred. It is probable that the approach has been chiefly, perhaps entirely, on the side of natalica, which has adjusted markings of a type usual among Ethiopian Acræinæ in such a manner as to produce superficial similarity to anemosa, an Acræa in which a very remarkable and unusual appearance is the warning sign of exceptional defence against insect-eating animals (see p. 413).

Mr. Marshall informs me that the two species are very similar upon the wing, and that the resemblance is much closer in the case of the female natalica than the male, thus following the rule in mimicry, and confirming still further the opinion expressed above that the approach has been from the side of natalica.

\section{Mimetic Species of South African Lycrnidre and Hesperidxe captured with their Models.}

Exclusive of Mimacræa marshalli and its form dohertyi 
which were discussed in relation to their models chrysippus and klugii, the groups containing Lycænidx or Hesperidx are considered below.

A group of the smaller Acræas with a single mimetic Lycænid was captured at Salisbury on Sept. 28, 1900. It contains the following species :-

\section{Acræa violarum, var. asema $\hat{\delta}$. \\ 1 , doubledayi, var. axina $\hat{\text { s. }}$ \\ 1 induna 1.}

1 Catochrysops mashuna $\hat{\delta}$ (figure of $q$ on Plate XIV, fig. 5).

A. induna falls into the first-mentioned group of small Acræas, resembling caldarena in the possession of a black apical patch to the fore-wing. The strong development of black spots upon an ochreous ground on the under-side of the Lycænid is doubtless mimetic in the position of rest, especially when in the company of Acræas or in places where they are likely to be found. Mr. Marshall informed Mr. Trimen "that on October 20, 1894, he saw two of this Lycrena sleeping on the end of a stem of dry grass among a number of Acrea nohara and A. caldarena, and was struck with the general similarity of their under-side to that of the Acræas; he also noticed that in the attitude of repose the fore-wings of the Lycina were well depressed between the hind-wings, giving the insect the elongate outline of an Acræa" (Trans. Ent. Soc. Lond., 1898, p. 6). $\mathrm{Mr}$. Trimen also suggests that the heavy black spotting of $L$. (C) gigantea and L. (C) perpulchra (Trim.) [= peculiaris, Rog.] is of the same significance, although the groundcolour is not Acræa-like in these species.

"Umkomaas Mouth, Natal; Sept. 3, 1897.-The underside of the Acræa-like Lycænid $L$. mashuna is ochreous yellow with large black spots, but I did not realize its resemblance to an Acræa until I saw them roosting together. The mimicry, however, is in a very incipient stage, for the yellow under-side fades somewhat rapidly, thus much lessening the resemblance; and, as it does not occur in its near allies $L$. hypoleuca and the fine $L$. gigantea, it is clearly a recently-acquired character."

In another group captured at Umtali, 3700 feet, in December 1900, the Acræas are only represented by a single 
species, and that not specially suitable as a model for the other members. The great interest of the assemblage is the presence of a rare Hesperid, A. tettensis, in which black spots and a pale pinkish tinge on the under-side of the hind-wings appear to indicate strongly-marked mimicry of Acræas on a line along which the above-named Lycænids have advanced to a greater distance. In another respect, however, viz. the strongly-marked black-and-white margin of the hind-wing under-side, the Hesperid is a much closer mimic of a general Acræa type. Mr. Trimen also speaks of the spotting and tinting of the under-side of both wings of this species as very peculiar and strongly recalling the aspect of some of the smaller Acræas (loc. cit., vol, iii, p. $338)$.

I have received from $\mathrm{Mr}$. Marshall the following references to the two Hesperids in the list of species making up this group :-

"Salisbury, Jan. 11, 1901.-I have recently obtained at Umtali another Hesperid, the very rare Abantis tettensis, showing strong Acræoid coloration on the under-side, which I will send you together with a Kedestes, which is of interest as it shows the incipient stages of such mimicry."

"Salisbury, Sept. 27, 1901.-I have never seen Abantis tettensis with its wings closed over its back; all that I have captured rested with wings expanded horizontally. Indeed I cannot at the moment recollect ever seeing any Abantis settle with vertical wings. I think it is highly probable that tettensis would sleep in that position, but under the circumstances I should not like to assume it as a fact without actually seeing it."

The group is as follows:-

3 Acræa encedon, type-form.

2 Catochrysops peculiaris (Plate XIV, fig. 4).

2 Abantis tettensis

1 Kedestes macomo, var. ( " ”, "7).

In the latter Hesperid the brilliant ochreous under-side affords an effective background for the small but distinct black spots on the under surface of both wings. The general effect is somewhat Acræa-like, but the tint of the under-side of most smaller Acræas is pinkish when they are fresh.

A more perfect Hesperid mimic is seen in the rare Baoris netopha, of which a female (Fig. 13, Plate XVI) was 
captured by Mr. Marshall at Salisbury on April 6, 1898, together with a male of Acria doubledayi, var. axina (Fig. 12, Plate XVI), which is one of the many smaller Acræas, to which it bears a somewhat generalized resemblance on the under-side of its wings in the natural position of rest, which is nearly but not quite represented in Fig. 13 (see the description of the Plate). Mr. Marshall has sent the following account of the attitude:-

"Salisbury, Feb. 12, 1899.-The Baoris netopha rest with closed wings, and the fore-wings pressed well within the hind-wings so as to hide the white spots; they then look much more Acræa-like."

The curious reticulate under surface of the hind wings of the isolated and remarkable Hesperid Cyclopides willemi is mimetic of the probably distasteful Alæra nyasse, which possesses a somewhat similar but much coarser reticulation. Mr. Marshall states that the resemblance is much enhanced in the resting attitude of both species by the concealment of the fore-wings, with the exception of the apex, within the hind. Both species frequent the same localities, and both rest upon grass-stems. One of each species was captured at Salisbury on Feb. 23, 1901, and another similar pair on March 3, 1901.

In thus bringing together Mr. Marshall's examples of mimicry in Hesperidx, it is appropriate to include the following interesting case of mimicry on the part of a Hesperid for a Danaine larva.

"Salisbury, March 10, 1898.- The larva of the large 'skipper' Rhopalocampta forestan possesses a colouring wonderfully similar to that of L. chrysippus, though it lacks the filaments. I only know the larvæ of three other species of Hesperidx and they are all green; moreover, they form shelters for themselves, and never come out to feed except after dusk; whereas, although forestan also forms a shelter, yet it frequently comes out and feeds in broad daylight, when it is a very conspicuous object."

The upper-side of Alsena nyasse appears to fit in with the strong combination of black-and-white Ethiopian butterflies belonging to the Danainx and Acræinx and their Batesian and Muillerian mimics. Among the smaller of the latter Neptis agatha is probably to be placed, and this species is on the wing with the much smaller Lycænid. Thus Mr. Marshall has sent to the Hope Department specimens of the Neptis captured at Salisbury on March 
19 and May 1, 1898, and of the Alsna taken on March 20 and April 3 of the same year.

It occurred to me that Castalius calice might also belong to the same group, but Mr. Marshall points out, in the passage quoted below, that its habits do not support this view.

"Salisbury, Jan. 8, 1899.-I should very much doubt whether Castalius calice is convergent with or even a mimic of Alana nyassx. Their habits and stations are very different, and moreover $C$. calice (of which I believe C. melana will prove to be the summer form) is common in Natal and the Transvaal, where A. nyasse does not occur. I should not regard $C$. calice as an unpalatable species, and its colouring is by no means conspicuous owing to its small size: it is an active little insect resembling T. plinius, Lycænesthes, and other arboreal Lycænidx in its habits. In the intense light and shade of this climate its black-and-white markings are rather protective as it rests on the shiny leaves of its food-plant (Zizyphus), just as are the brilliant white under-sides of some Iolai. The convergence you suggest between $A$. nyassa and Neptis agatha and Nyctemera leuconoe is highly probable, but Amauris and the black-and-white Acræas are all absent from the Mashona plateau, being all coast or low-veldt forms. Alrna, Pentila, and perhaps Deloneura, are in my opinion the only unpalatable South African Lycænidx, and the latter is more likely to be a mimic of some day-flying moth. Catochrysops mashuna used to be very abundant here, but only occurring in September and October. I only saw two or three this season and always when I had no net."

Three specimens of another interesting and probably distasteful species of the same Lycænid genus Alæna amazoula captured on the same day, Sept. 26,1897 , as the conspicuous day-flying and probably unpalatable geometrid moth Petovia dichroaria were presented by Mr. Marshall to the Hope Department. Mr. Marshall had taken the group in the same locality at Malvern, Natal, and, as the passage from his letter quoted on p. 498 indicates, he believes that the resemblance is synaposematic. In the cabinet the likeness is stronger on the under than upon the upper surface, but is probably strongest of all upon the wing.

Alæna amazoula is a Lycæuid of great interest, probably exhibiting a generalized Muillerian resemblance to the

TRANS. ENT. SOC. LOND. 1902. - PART III. (NOV.) 33 
Acræas. Although unlike any single species of Acræa, the likeness to this group and unlikeness to the Lycænidx was sufficient to deceive Boisduval and at first Roland Trimen (Rhop. Afr. Austr., 1862-66, p. 111). In the Hope Collection also $I$ found it had been placed among the Acræas by Professor Westwood. Its undoubted Lycænir affinities were finally established by Roland Trimen ("South African Butterflies," vol. ii, 1887, p. 222).

The above-mentioned errors as to the affinity of this aberrant Lycænid certainly support the opinion that it bears a general resemblance to the Acrixinx. It would be interesting to know its resting habits. With the underside exposed and the long narrow wings it would probably bear some general likeness to a very small Acræa. Mr. Marshall wrote concerning it as follows :-

"Umkomaas Mouth, Natal; Sept. 3, 1897.-Alrena amazoula is certainly a protected species, but I do not think it is in any way convergent towards the Acræas, for it is in no way suggestive of them on the wing, being by no means conspicuous, but rather difficult to follow. Its length of wing has been attributed to relationship with Acræa, but this seems open to doubt. I should prefer to consider it as a parallel development to Acræa, though it is worth noting that the allied genus Lachnocnema has also somewhat elongate wings."

"Malvern, Oct. 7, 1897.-The day-flying moths [Petovia dichroaria] captured on the same day as Alina amazoula can, I think, be well regarded as convergent in coloration."

\section{J. Mimicry in Lycrnidx and to a less extent in Hesperide a Character of the Ethiopian Region. Possible Inter- pretation.}

The instances of mimicry in South African Lycrnidx recorded here, and the much larger number known in other parts of the region, especially the tropical West Coast, led me to inquire how the total number of species of this family compared with that of other parts of the world. My friend Mr. Hamilton Druce kindly made an approximate calculation of the number of described species in the two other great tropical south-extending land masses. From Australia, the Malay Archipelago, and the continental portion of the Oriental Region, over 1000 species have been described. From the Neotropical Region 
about 700 species of Thecla have been described. In Aurivillius' catalogue of Ethiopian Rhopalocera only 582 species are recognized. The predominance of Lycænid mimicry in this latter Region is therefore in no way connected with richness in the number of species. The chief reason is certainly the existence in the Region of the sub-family Lipteninx, with nearly all its species mimetic. In addition to the general Acræine appearance of Alæna amazoula, the Neptis-like A. nyassi and the chrysippus-klugii-like Mimacræa marshalli-dohertyi, there is represented in the Hope Collection mimetic resemblance to Terias or other small Pierines on the part of Larinopoda liresa, L. tera, Liptena libyssa, and L. undularis ; to Mylothris by Pentila abraxas, P. phidia, and Citrinophila erastus; to chrysippus and the chrysippus-like Euphrdra and Aletis by Telipna bimaculata and T. sanguinea; to a general Acræine type by two or three species of Pentila. Many other cases of mimicry are known in the sub-family, especially towards models of the genera Planema and Acraca (see Aurivillius, loc. cit., p. 530). But this remarkable group does not by any means exhaust the Ethiopian Lycænid mimics, for many species of the Lycæninæ mimic Acræas, Terias or other small Pierines and Mylothris. The general Acræine mimicry of species of Catochrysops has already been described and illustrated. Furthermore, Aurivillius considers that there is a certain amount of mimetic approach between species of Lipteninx and Lycæninæ in which the former probably always act as models.

It is very difficult to understand this predominance of Lycænid mimicry in the Ethiopian Region, and I can only suggest the possibility that the number of feasible models of moderate and small size furnished by the abundant Acræinæ of Africa may furnish an explanation. In such cases as Catochrysops peculiaris and mashuna we see at once how naturally and easily the Lycænid under-side adapts itself to the characteristic appearance of the Acræc type, especially when it is further assisted by similar habits. And this suggests another equally important principle which has doubtless been fertile in bringing about Lycænid mimicry, viz. the habits of the models being such as to bring them within the range of the forms which were to mimic them. The numerous low-flying and low-settling Acræas, resting at night on grass-stems, have precisely the mode of life which is well known to be characteristic of 
such a large number of Lycænidx. The Lipteninx are probably a specially-protected group, and the rarity of many of the species may be only apparent, and due to their (Muillerian) mimicry of extremely common forms for which they are constantly mistaken by naturalists.

In other parts of the world Lycænidæx which are evidently specially protected and extremely conspicuous are well known, such as Talicada of the Oriental Region and Eumæus of the Neotropical. These genera do not enter into synaposematic association with the best-defended butterflies of their localities, but each adopts an aposematic appearance peculiar to itself. It is probable that in the Neotropical Region, where mimicry is more striking and more fully exemplified than in any other part of the world, the habits of the Theclas are the chief obstacle to their use of this means of protection. For models of all sizes abound in this part of the world. On the other hand, in the tropical East it may be the want of a sufficient number of models of an appropriate size and habits which has acted as the barrier.

The explanation which has here been thrown out as a suggestion may also enable us to understand the cases of mimicry in Ethiopian Hesperidx, a family in which such resemblances are rare. Here, however, the facts may be paralleled in the Neotropical Region where there are a few mimetic "skippers." Mimicry in this group and the want of it in the Lycrnidx may follow from the difference between the habits and stations of the tropical American Hesperids and Theclas.

\section{K. Mimicry in the Nymphalinx Batesian or Müllerian?}

I have had much controversy with my friend $\mathrm{Mr}$. Marshall over this difficult and interesting problem, and I propose to bring forward a résumé of the arguments which seem to support the latter interpretation as opposed to the former, and then to quote his weighty objections and the interesting observations of the habits of mimetic species and genera which he has made.

1. It is of interest although probably not of extreme importance to reflect that all the great groups of unpalatable, conspicuous, and much-mimicked butterflies belong to the Nymphalidx-the Ithomiinx, Danainx, Heliconinx, and Acrxinx, and that the two latter are so 
closely related to the Nymphaline that it is difficult to draw a line between them. The argument is not of much weight, because the intensely procryptic habits and colours of many Nymphaline genera have certainly been brought about by selection due to the great keenness and success of insect-eating animals in their pursuit. I have however suggested and brought evidence in support of the view that some of the procryptic Nymphaline species are to a certain extent unpalatable (see p. 442).

2. Mimicry in the Nymphalinx does not appear in isolated forms but in all or nearly all the species of a genus. Such mimetic genera are usually very large, dominant, and wide-spread. The species themselves are also often wide-spreading, and may have an enormous range far exceeding that of the model (Hypolimnas misippus). Allowing for the fact that the mimetic species resemble the commonest types in the world, and so are liable to escape notice, it is probable that they are rich in individuals. In many instances we know that this is so. The more we investigate it the more does Rhopaloceran mimicry seem to be associated with dominant genera and species, rather than the feeble and hard-pressed forms which H. W. Bates presupposed in his well-known theory.

3 . The dominant tendency towards mimetic resemblance in any genus cannot be explained by hereditary transmission of the mimetic form of a single parent species, or from the tendency of closely-related species to vary along nearly the same lines, because the species of a mimetic genus, as a matter of fact, mimic in many different directions. Thus Pseudacræa resembles Acræa, Planema, Amauris, and Limnas chrysippus; while Hypolimnas, including Euralia, is even more protean.

4. The non-mimetic species of a mimetic genus are often markedly conspicuous, exhibiting what has all the appearance of an aposematic pattern peculiar to themselves (Hypolimnas, Pseudacræa). This is also frequently true of the non-mimetic males of a species with mimetic females (Hypolimnas). Such aposematic patterns are especially displayed on the under-side, where procryptic colours are developed in other butterflies.

5 . The converse of the last argument is also true, viz. some of the species in a genus, which is as a whole markedly conspicuous and itself mimicked, are often mimetic of quite other groups. Many instances of Neptis 
have been given on pp. 467, 468, and mimetic species are also well known in Limenitis, Cethosia, etc.

6 . The non-mimetic species of mimetic genera are sometimes mimicked; e.g. the mimicry of the nerina form of female Hypolimnas bolina by a rare Danaine in Celebes, etc. The resemblance of the upper-side of certain species of Protogoniomorpha to some of the larger species of Hypolimnas may be another instance of the same tendency.

7. The fact that mimetic species resembling some primary model nevertheless in certain respects resemble each other rather than the model. This deuterosynaposematic resemblance, as it may be called, is a very widespread phenomenon, and several striking instances of it are discussed in the present memoir (see pp. 470, 471, 485-7). It will also be shown to occur in Coleoptera (pp. 513-515).

I have given merely an outline of the chief evidence which has induced me to believe that the mimetic Nymphaline genera are to some extent specially protected, and thus have developed a beneficial synaposematic association with far better protected forms belonging to other sub-families.

This evidence has been sought and obtained under the guidance of the principles discovered by Dr. F. A. Dixey and ably presented by him in 1894-97 (Brit. Assoc. Reports, 1894, pp. 692, 693; Trans. Ent. Soc. Lond., 1894 , p. $298 ; 1896$, p. 65 ; 1897, p. 317). These memoirs mark one of the few important advances made in our attempt to understand the complex and difficult phenomena of mimicry. I will quote one pregnant paragraph, which it will be seen contains the essence of what I have here described as primary and secondary mimicry (see pp. $513-515$, also the above paragraph 7). "Every conspicuous and distasteful form is a centre of attraction for other forms, whether edible or inedible; but in the former case (Batesian mimicry) the mimetic attraction is limited in operation, and acts only in one direction, influencing nothing but the mimic; while in the latter case (Miillerian mimicry) the mimetic attraction is unlimited and mutual, acting reciprocally in both directions, and influencing each member of the group" (Trans. Ent. Soc. Lond., 1897, pp. 324, 325).

Mr. Marshall's valuable notes on the habits of Nymphaline mimics and his discussion of the conclusions described 
above, are contained in the following quotations from his letters.

"Malvern, Natal; Feb.21, 1897.-As regards the Euralias my experience of them is somewhat limited, but from what I have seen of them I feel pretty sure that their coloration is due to mimicry and not to convergence. Their range seems in all cases to agree with that of the Amauris they resemble. In Durban $A$. ochlea is by far the scarcest of the three, and its mimics E. deceptor and Pseudacræa expansa are also very rare; further up the East Coast, however (Delagoa Bay and Beira), ochlea becomes one of the commonest of the genus, and the two other species are likewise much more numerous. At this place, it is true, Euralia wahlbergi is certainly more plentiful than $A$. dominicanus, but they are both uncommon, and all the specimens we see are practically visitors from the thick bush along the immediate coastline. (This is six miles inland.)",

"I may mention that in the last few years Mr. Ball has caught two Euralia wahlbergi [in the Karkloof Forest twenty miles $\mathrm{N}$. of Maritzburg], but has never seen Amauris dominicanus."

"Umkomaas Mouth, Natal; Sept.3, 1897.-With regard to the Euralia, etc., I must admit that I have never been fully convinced by the contention that in Batesian mimicry the mimetic species must of necessity be a feeble one and very few in numbers. It seems to me that it would be quite reasonable to suppose that such a mimic might well equal or even exceed in numbers the protected species, though this would of course depend entirely upon the degree of inedibility of the latter. For example, in the case of Euralia mima and Amauris echeria (probably the bestprotected butterfly here), supposing they occur in equal numbers in a given area, and that certain birds by chancing to catch three or four of the former in succession were induced to prey upon butterflies with that coloration, then, from a mathematical standpoint, every alternate specimen caught by any bird would be A. echeria. Now I think we are quite safe in assuming that the fact that every other butterfly caught had a nauseating taste and smell would be far and away more likely to create a strong and lasting impression upon a bird's mind than the fact that every second one proved to be edible, 
and would be quite sufficient to deter the bird from attempting to eat butterflies of that colour. This is from a mathematical point of view solely, but, from what I know of these two forms in life, I believe that presuming them to occur in equal numbers, a larger proportion of echeria would actually be captured, for mima is a much more shy insect, and although it has the same slow sailing flight (when undisturbed) it does not keep on the wing nearly as long as echeria; moreover, it is much more wary and always on the alert for danger, going off at a smart pace when frightened, and not returning to the same spot as echeria frequently does after being struck at; altogether it is a much more difficult insect to capture. Indeed I do not see why the mimic should not even somewhat surpass the mimicked species in numbers, without upsetting their relations to one another, provided the taste of the latter be sufficiently unpleasant, and particularly if the flavour be of a lasting nature."

"Malvern, May 14, 1897.-I feel quite satisfied that Pseudacrea trimenii is a mimetic and not a protected species. In spite of its larger size it looks wonderfully like Acræa acara on the wing, and the first few examples I caught completely took me in. Their flight is like that of all Pseudacræas and Euralias-slow and sailing-so long as they are not disturbed; but if struck at and missed they are off like a shot and do not often give one a second chance. At this particular spot (Malvern) they are a good deal commoner than $A$. acara, which is only a rare visitor. The latter is however common on the immediate coast, where $P$. trimenii is I am told pretty plentiful in good seasons."

"Salisbury, Jan. 12, 1901.-I quite agree with you that the resemblance between the under-sides of Delias pandemia and Isbarta pandemia is the most remarkable case yet brought forward, and one cannot but marvel how such exact similarity can have been arrived at. Although I should certainly incline to the belief that the mimicry is Müllerian, judging by the congeners of both forms, yet its very exactitude seems to be a difficulty, for although one can readily understand how in an edible and muchpersecuted species the resemblance might be brought up to so high a grade, yet it is hard to understand how this could be effected in a species which is comparatively immune from attack. For it seems to be an inevitable 
deduction from the theory of mimicry that a high grade of resemblance must imply excessive persecution, either now or within recent times, unless we are prepared to admit some other convergent force."

"Salisbury, Sept. 27, 1901.-With regard to Müllerian mimicry I quite agree that the slow flight and the bright colours of protected forms would lay them open to much experimental tasting from inexperienced birds; but the extreme toughness of their integuments (for example in the Acræas) and their great vitality seem to have been specially developed to minimize this danger. And whereas the Batesian mimic, if thus experimented with, would promptly be eaten, a Müllerian butterfly would run a very good chance of surviving its injuries and propagating its kind. Do not suppose that $I$ in any way disbelieve in the action of Muillerian mimicry, for I certaialy think it must be a very strong factor. But this point seems to me to be a real difficulty, and I should like to be able to answer it satisfactorily if it were brought up by an opponent."

\section{Miscellaneous Observations on Mimicry in South African Rhopalocera. (G. A. K. M.)}

\section{a. Nymphalinæ.}

"Malvern, Natal; Feb. 21, 1897.-I do not remember ever having scen it suggested that the female of the handsome Charaxes xiphares mimics A. echeria, but I have little doubt that such is the case. It is a fairly common species at the Karkloof, but difficult to eatch, and I only took one. I believe there are more instances of mimicry in this genus, e.g. achrmenes and guderiana, of which the females are very scarce (though the male of the former is one of the commonest Charaxes in Mashonaland) and very differently coloured from the males, being remarkably like the common widespread C. saturnus. Again, some years ago I pointed out to Trimen the strong resemblance of the female of $C$. whytei to Neptis agatha on the wing. I hope to be able to prove before long that Neptis is a distasteful genus (by the way, is Limenitis edible?), as its appearance and habits certainly point that way."

3. Pierine.

"Estcourt, Natal; Oct. 15, 1896.-In Durban Mylothris 
agathina was fairly abundant, and I was interested to notice the very close resemblance between it and Belenois thysa, though, as is the case with most mimics, the latter has a much quicker flight when disturbed. B. thysa, so far as my experience goes, is confined to the warm coast belt, whereas $M$. agathina is common everywhere throughout South-east Africa."

"Malvern, March 12, 1897.--It is curious to note that although Nepheronia argia was common at the Karkloof, I never saw a single specimen of Mylothris agathina. Mr. Ball has in his collection a very fine variety of the female of the former, which clearly mimics Mylothris trimenia, the upper-side of the hind-wings being lemon-yellow, and the red mark on the under-side of the fore-wings absent. This is the only one I have seen, although I took one or two females showing an approach towards it, one of which I send you."

"Umtomaas Mouth, Natal; Sept. 3, 1897.-I am afraid I can hardly bring myself yet to believe in Dixey's theory that the Pierinx are for the most part protected. As regards our South African species, the only ones which I feel confident are protected are Mylothris agathina, ruppellii, and trimenia, and Pontia hellica. For the remainder I think we must find some other cause to account for their numbers and wide range. In Terias the larva possesșes wonderfully assimilative colouring, and is extremely difficult to detect on the food-plant, and so far as the experience of Hutchinson and myself goes with T. brigitta we have never yet, observed a single case of parasitism. The protective coloration and comparative freedom from parasites of the larva, and the protective seasonal colouring of the imago, would no doubt go a long way to explain their number, though I fancy there must be some other factor."

"Salisbury, May 1, 1899.-Query: are the black bands in the females of Teracolus acquired in mimicry of the common and widespread species, Herpænia eriphia?"*

\section{$\gamma$. Papilionina.}

"Salisbury, Dec. 26, 1897.-Papilio brasidas I consider

* Dr. F. A. Dixey informs me that Professor Westwood probably suspected a relationship between the markings of $H$. eriphia and T. eris, for he had removed a specimen of the former species from the others, and placed it next to a dry form of the Teracolus. 
to be merely a local race of $P$. leonidas, as every one must do who has seen a long series of the two forms. I have found typical leonidas pretty plentifully in the low veldt of Mashonaland (Mazoe and Umfuli Rivers) and I also saw it at Delagoa Bay. I have always been struck with its marked difference in habit from the Southern brasidas. Its flight is strong and rapid, and it always goes straight ahead like $P$. policenes and $P$. anthens, which it somewhat resembles on the wing in spite of its very different shape. Brasidas, on the other hand, has a slow sailing flight, going backwards and forwards over the same ground and often frequenting one spot for days. Now there is absolutely nothing suggestive of protection in the flight of leonidas, none of that slow sailing movement to show off its coloration which is so characteristic of the protected Danainæ and Acræinæ. Moreover, there is no Danaine occurring south of the Zambesi which is anything like it at all, and this is very significant. I cannot therefore resist the conclusion that in this country leonidas is one of those unprotected species which has succeeded in the struggle for existence by its strong rapid flight, and perhaps by protection in the larval stage like $P$.demodocus and $P$.corinneus, whereas in Natal it has found it advantageous, owing to the abundance of Amauris echeria, to adapt its coloration in mimicry of that species by the reduction in size and number of the spots in the fore-wing and the toning down of the colour from glaucous green to greenish-white, accompanied by the marked change in its mode of flight. It does not seem to me that convergence would explain the facts, for if leonidas is itself protected it should exhibit throughout its range that slow flight which is the 'hall mark' of protection, which it certainly does not in Mashonaland. I believe in Central Africa it is said to mimic T. petiverana, and it would be most interesting to find out whether it has there assumed the Danaine flight."

"Malvern, Feb. 21, 1897.-I have been collecting in the Karkloof Forest some twenty miles north of Maritzburg for the last three weeks. The only Amauris occurring there is echeria, which is very common, though not this year, which is a curiously abnormal one, and as usual the typical female of Papilio cenea is common, the dominicanuslike form occurring only very rarely. But last year, so my host Mr. Jas. Ball informs me, the latter was very abundant-quite as common as the typical one, and he 
caught a long series of them. It seems clear they were not immigrants from Durban, but what caused their appearance in such unusual numbers it is difficult to understand. I may mention that in the last few years Mr. Ball has caught two E. wahlbergi but has never seen dominicanus. While there, I saw six females of $P$. cenea, two of each of the three forms."

\section{Warning Colours and Mimicry (almost wholdy Müllerian) in South African Coleoptera. (G. A. K. M., E. B. P.)}

[In the groups described below, Coleoptera play a dominant part, either making up the whole or, except in the case of the Mutilloid group, acting as models for other insects. In this one exception the chief interest centres in the Coleoptera, and therefore the group is included here. A certain number of mimetic Coleoptera will be mentioned elsewhere in other groups which have collected round various types of Hymenopterous models.

In the present section the extraordinary predominance of Miillerian associations in South African Coleoptera stands out as the most prominent conclusion.-E. B. P.]

\section{A. Peculiar Warning Patterns and Directive Marks in} Carabidex and Cicindelidx. (E. B. P., G. A. K. M.)

Some of the warning patterns of the large Carabidx of the genus Anthia are very remarkable and effective, and their development and relationship in the different species extremely interesting.

Six illustrative examples are figured on Plate XVII. In Fig. 21 we see the ancestral appearance, the uniform black of so many large Carabids, in Anthia massilicata. Mr. Marshall's account of the habits of the South African members of the genus, printed on page 510, shows that such a beetle is highly conspicuous. It is no doubt an advantage, however, to gain easily-recognizable distinctive marks on the black ground of the exposed dorsal surface, and we find that the species of Anthia do, as a rule, possess two or more white patches upon some part of this area. The pair of elongated thoracic white patches, in A.petersi (Fig. 22), are borne upon the sides of a thorax which is very like that of massilicata, while in A. thoracica (Fig. 23) this part of the body is greatly widened and the white patches 


\section{$2 \mathrm{BHL}$ Biodiversity Heritage Library}

1902. "30. Description and Discussion of Material bearing on Mimicry in South African Rhopalocera collected by Guy A. K. Marshall, and the Record of Observations made by him. (E. B. P.)." Transactions of the Entomological Society of London 50, 466-508. https://doi.org/10.1111/j.1365-2311.1902.tb02421.x.

View This Item Online: https://www.biodiversitylibrary.org/item/48243

DOI: https://doi.org/10.1111/j.1365-2311.1902.tb02421.x

Permalink: https://www.biodiversitylibrary.org/partpdf/25272

\section{Holding Institution}

Smithsonian Libraries

\section{Sponsored by}

Smithsonian

\section{Copyright \& Reuse}

Copyright Status: Public domain. The BHL considers that this work is no longer under copyright protection.

This document was created from content at the Biodiversity Heritage Library, the world's largest open access digital library for biodiversity literature and archives. Visit BHL at https://www.biodiversitylibrary.org. 